\title{
ANALISIS LOG TOC PASSEY DAN PENYEBARAN SERPIH PINIYA MENGGUNAKAN METODE SEISMIK INVERSI, CEKUNGAN AKIMEUGAH
}

\author{
Winda Putri Anggraeni*, Jarot Setyowiyoto and Ferian Anggara
}

\section{Ringkasan}

Cekungan Akimeugah memiliki potensi hidrokarbon dengan adanya beberapa rembesan minyak dan gas bumi disekitar daerah penelitian. Hal ini mengindikasikan adanya sistem minyak dan gas bumi yang bekerja pada daerah tersebut. Serpih Piniya merupakan salah satu formasi yang berpotensi menjadi batuan induk sekaligus batuan reservoar yang baik. Batuan induk yang mengandung hidrokarbon ditentukan oleh kuantitas material organik (Total Organic Carbon). Untuk itu, perlu diketahui kuantitas material organik (TOC) serta penyebaran dari Serpih Piniya.

Serpih Piniya disusun oleh litologi dominan serpih dengan sisipan batulanau dan batupasir. Formasi ini diendapkan pada lingkungan laut dangkal (shallow marine) dengan asosiasi fasies offshore transition hingga offshore. Jumlah kuantitas material organik (TOC) dari data sampel sebesar $0.552 w t \%$ termasuk ke dalam kategori batuan induk yang bersifat cukup (fair). Tipe kerogen Serpih Piniya adalah tipe II - III yang dapat menghasilkan hidrokarbon minyak dan gas. Litofasies serpih yang dapat menghasilkan hidrokarbon adalah organic shale. Interval organic shale terdapat pada sumur AK-6 sebanyak 46 zona dan sumur AK-9 sebanyak 34 zona. Perhitungan TOC Passey menghasilkan nilai TOC rata-rata sebesar $0.527 w t \%$ menandakan Serpih Piniya berada pada kategori batuan induk yang bersifat cukup.

Penyebaran nilai TOC menggunakan seismik inversi untuk mengetahui model geologi bawah permukaan. Penyebaran nilai TOC tinggi ditandai dengan nilai impedansi akustik yang rendah, area tersebut terletak pada bagian rendahan daerah penelitian. Area sweet spot secara umum berada disekitar sumur AK-2, area tersebut memiliki nilai TOC berkisar $0.552 w t \%$ dengan ketebalan Serpih Piniya kurang lebih sebesar $1200 \mathrm{~m}$.

Kata Kunci : TOC Passey, Seismik Inversi, Serpih Piniya.

\section{Abstract}

Akimeugah Basin has hydrocarbon potential with some oil and gas seepages around the research area. This indicates the existence of an petroleum system that works in this area. Piniya Shale is one of the formations which has the potential to become a source rock as well as good reservoir rock. Source rock that containing hydrocarbons was determined by the Total Organic Carbon. For that reasons, it is necessary to know about quantity of Total Organic Carbon and the distribution of Piniya Shale.

Piniya Shale are composed by the dominant of shale with intercalation of siltstone and sandstone. This formation is deposited in shallow marine with offshore transition and offshore as facieas associations. Total organic carbon from sample data is $0.552 w t \%$, its meaning Piniya Shale in the category fair as a source rock. Kerogen type Piniya Shale are type II - III which can produce oil and gas hydrocarbon. Litofacies of shale that can produce hydrocarbons are organic shale. The organic shale interval was found in the AK- 6 wells as 46 zones and AK-9 wells as 34 zones. TOC Passey calculation produce TOC value of $0.527 w t \%$ that indicates Piniya Shale in the category fair as a source rock

Distribution of TOC Passey using seismic inversion to determine subsurface geological models. Distribution of TOC shows that high TOC was indicates by a low acoustic impedance value, the area is located in the lower part of the research area. The sweet spot area is around the AK-2 well, the area has TOC value range from $0.552 w t \%$ with thickness approximately 1200 meters.

Keywords: TOC Passey; Seismic Inversion; Piniya Shale. 


\section{PENDAHULUAN}

Jumlah cadangan minyak dan gas bumi konvensional dari tahun ke tahun mengalami penurunan. Menghadapi tantangan ini, pemerintah berupaya untuk meningkatkan penemuan-penemuan cekungan yang berpotensi sebagai sumber daya energi alternatif yang dikenal dengan minyak dan gas bumi non konvensional. Hidrokarbon serpih sebagai minyak dan gas bumi (migas) non konvensional. Hidrokarbon serpih adalah hidrokarbon yang diperoleh dari batuan induk atau source rock berupa serpih yang terperangkap dalam batuan induk itu sendiri.

Batuan induk yang mengandung hidrokarbon ditentukan oleh kuantitas material organik (Total Organic Carbon). Formasi Piniya adalah formasi yang berpotensi menjadi batuan induk pada Cekungan Akimeugah. Formasi Piniya didominasi oleh serpih dengan sisipan batulanau dan batupasir yang memiliki ketebalan 900 m (Panggabean dan Hakim, 1986)[4]. Sukhyar dan Fakhrudin (2013)[7] menjelaskan bahwa Cekungan Akimeugah memiliki potensi untuk menghasilkan hidrokarbon serpih terutama shale gas sebesar 62.64 TCF.

Pada tingkat kematangan tertentu, material organik akan berubah menjadi hidrokarbon cair maupun gas dan terekam. Perubahan tersebut terekam oleh respon data log sumur seperti log resistivitas. Untuk mempelajari respon data log sumur maka pada penelitian ini, dilakukan analisis TOC menggunakan teknik $\Delta \log$ Resistivity.

Persebaran TOC Serpih Piniya menggunakan metode seismik inversi. Seismik inversi adalah teknik membuat model bawah permukaan menggunakan data seismik dan dikontrol dari data sumur (Sukmono, 2000)[8]. Inversi Acoustic Impedance (AI) adalah salah satu metode seismik inversi post-stack inversion. Seismik inversi AI menghasilkan model geologi sehingga dapat mengetahui penyebaran lapisan target.

Berdasarkan analisis log TOC pada data sumur dan penyebaran TOC menggunakan metode seismik inversi akan menghasilkan area yang berpotensi menghasilkan hidrokarbon dari Serpih Piniya.

\section{METODELOGI PENELITIAN}

Penelitian ini dilakukan pada menggunakan data log sumur, data Side Wall Core (SWC), data Mudlog, data biostratigrafi, data geokimia organik, data seismik 2D, dan data checkshot. Data sumur yang digunakan untuk penelitian terkait log TOC dan persebaran

\footnotetext{
${ }^{*}$ Correspondence: windaputrianggraeni@gmail.com

Departemen Teknik Geologi, Fakultas Teknik, Universitas Gadjah Mada,

Daerah Istimewa Yogyakarta, Indonesia

Full list of author information is available at the end of the article

${ }^{\dagger}$ Equal contributor
}

adalah sumur AK-6 dan sumur AK-9. Penelitian ini dilakukan dengan beberapa tahapan penelitian untuk tercapainya tujuan yang dimaksud (Gambar 1).

\section{A. Metode $\Delta \log R$}

Perhitungan log TOC menggunakan metode Passey et al. (1990)[5] dengan melakukan crossover antara log resistivitas dan log sonik. Untuk batuan induk dapat dikatakan matang, maka log sonik interval batuan tersebut harus berada di sebelah kiri log resistivitas. Kemudian nilai $\Delta \log R$ dituliskan sebagai persamaan:

$$
\Delta \log R=\log _{1} 0 \frac{R_{t}}{R_{\text {baseline }}}+0.02 x\left(\Delta T-\Delta T_{\text {baseline }}\right)
$$

Keterangan:

$\Delta \log R$ : Nilai crossover log resistivitas dan log sonik $R_{t}$ : Nilai deep resistivity $\log (\Omega)$

$R_{\text {baseline }}$ : Resistivitas pada pusat crossover resistivity $\log$ dan $\log$ sonik $(\Omega)$

$\Delta T$ : Nilai log sonik $(\mu s / f t$ atau $\mu s / m)$

$\Delta T_{\text {baseline }}:$ Sonic transit time pada pusat crossover resistivity log dan log $\operatorname{sonik}(\mu s / f t$ atau $\mu s / m)$

Nilai TOC menggunakan metode ini kemudian didapat dengan persamaan :

$$
T O C=\Delta \log R \times 10^{102.297-(0.1688 \times L O M)}
$$

Keterangan:

TOC : Nilai kandungan TOC dalam batuan (\%)

$\Delta \log R$ : Nilai crossover resistivity log dan log sonik

\section{B. Post - stack Inversion}

Amplitudo dari sebuah data seismik merupakan besarnya jumlah energi yang terpantulkan ke permukaan bumi dan direkam oleh receiver. Sedangkan besarnya energi yang terpantulkan tergantung besarnya nilai koefisien refleksi (RC). Secara umum jejak seismik merupakan hasil konvolusi antara wavelet sumber dengan $\mathrm{RC}$ dan ditambah dengan komponen bising.

$$
S(t)=W(t) x R C(t)+n(t)
$$

Keterangan:

$S(t)$ : trace seismik

$R C(t)$ : koefisien refleksi

$W(t)$ : wavelet

$n(t)$ : noise 
Proses post-stack inversion adalah salah satu jenis dari proses inversi. Inversi dapat dipahami sebagai proses pembuatan model impedansi akustik untuk mendapatkan nilai besaran suatu sifat batuan pada arah lateral yang terikat kuat dengan sifat impedansi akustik (Atarita et al., 2017)[2]. Post-stack inversion dapat dipahami sebagai proses inversi yang dilakukan terhadap data seismik post-stack (Alves et al., 2014)[1]. Proses inversi yang menggunakan data seismik post-stack hanya dapat menghasilkan satu model impedansi saja, yaitu impedansi dari gelombang primer atau P-wave impedance (Alves et al., 2014)[1].

Pembuatan model inversi dimulai dari membuat model impedansi pada data seismik dan data sumur. Karena data seismik yang digunakan adalah data post-stack seismic, maka menurut Alves, et al. (2014)[1], impedansi dapat dirumuskan sebagai persamaan :

$$
I=\rho x V_{p}
$$

Keterangan:

$I$ : Impedansi akustik $\left(\mathrm{kg} / \mathrm{m}^{2} \mathrm{~s}\right)$

$\rho$ : Massa jenis batuan $\left(\mathrm{kg} / \mathrm{m}^{3}\right.$ atau $\left.\mathrm{gr} / \mathrm{cc}\right)$

$V_{p}$ : Kecepatan gelombang primer $(\mathrm{m} / \mathrm{s})$

Besarnya nilai RC dipengaruhi oleh besarnya kontras impedansi akustik (acoustic impedance/ AI).

$$
R C=\frac{A I_{i+1}-A I_{i}}{A I_{i+1}+A I_{i}}
$$

Keterangan :

$R C$ : Reflection Coefficient

$A I_{i}$ : Acoustic Impedance lapisan i

$A I_{i+1}$ : Acoustic Impedance lapisan di atas lapisan i

Impedansi akustik merupakan parameter batuan yang dipengaruhi oleh litologi, porositas, kandungan fluida, kedalaman, tekanan, dan suhu sehingga impedansi akustik dapat digunakan untuk identifikasi parameter-parameter batuan yang mempengaruhinya. Impedansi akustik ini kemudian dapat digunakan untuk melakukan P-Impedance Inversion. Model P-Impedance Inversion ini kemudian dapat dikorelasikan dengan berbagai sifat batuan yang ingin disebarkan secara lateral seperti TOC dan $S_{2}$ (Atarita et al., 2014). Umumnya, nilai impedansi akan berbanding terbalik dengan nilai TOC dan $S_{2}$.

\section{Penyebaran TOC menggunakan Seismik Inversi}

Loseth et al. (2011)[3] menjelaskan data seismik shale dapat dipetakan apabila memiliki ketebalan lebih dari $20 \mathrm{~m}$ atau memiliki ketebalan yang lebih besar dari ketebalan tuning. Property batuan seperti kekayaan materi organik (TOC) ditunjukkan oleh nilai impedansi akustik yang menurun secara non-linier dengan meningkatnya nilai TOC.

Loseth et al. (2011)[3] juga menjelaskan bahwa shale yang memiliki nilai TOC yang tinggi memiliki nilai densitas yang lebih rendah dan pada data seismik ditunjukkan oleh respon amplitudo terang (bright amplitude). Sedangkan, lapisan yang memiliki nilai brittleness yang rendah akan ditunjukkan dengan respon amplitude rendah.

Berdasarkan karakteristik yang ada, keberadaan lapisan shale, ketebalan, dan variasi konten materi organik secara lateral dapat dipetakan menggunakan data seismik. Data seismik impedansi akustik pada interval lapisan shale dapat ditransformasikan menjadi nilai TOC apabila mendapatkan nilai kalibrasi data sumur yang baik (Gambar 2).

\section{HASIL DAN PEMBAHASAN}

\section{A. Litofasies dan Lingkungan Pengendapan}

Pengamatan kualitatif pada data log sumur seperti volum serpih, nilai log gamma ray, arah defleksi $\log$ spontaneous potential, dan defleksi log caliper digunakan sebagai langkah awal untuk menentukan litofasies pada sumur penelitian. Data Side Wall Core (SWC) dan Mudlog digunakan untuk mendukung interpretasi litofasies pada data log sumur dari informasi deskripsi batuan melalui data cutting.

Hasil analisis stratigrafi pada sumur AK-2, sumur AK-6 dan sumur AK-9 menunjukkan bahwa Formasi Piniya tersusun atas litologi dominan berupa serpih (shale) dengan sisipan batulanau (siltstone) dan batupasir (sandstone). Serpih berwarna abu-abu kehitaman, blocky, menyerpih dan bersifat agak karbonatan.

Lingkungan pengendapan Formasi Piniya adalah laut dangkal (shallow marine). Litofasies dominan serpih dengan sisipan batulanau dan batupasir menjadi dasar Formasi Piniya mempunyai asosiasi fasies offshore transition pada bagian atas, sedangkan hadirnya interval dengan litofasies dominan berupa serpih pada bagian bawah diinterpretasikan sebagai fasies offshore. Korelasi sumur pada daerah penelitian dapat dilihat pada Gambar 3.

\section{B. Analisis Geokimia Serpih Piniya 1. Kuantitas Material Organik}

Kandungan TOC dalam batuan mewakili seberapa baik batuan dapat menjadi sumber hidrokarbon. Secara logika, semakin tinggi nilai TOC maka akan semakin baik pula kualitas batuan untuk menjadi 
sumber hidrokarbon. Berdasarkan kandungan TOC sampel cutting (Gambar 4), TOC Serpih Piniya sumur AK-2, AK-6 dan AK-9 mempunyai nilai berkisar antara $0.06-1.96 w t \%$. Secara umum, Serpih Piniya termasuk dalam kategori batuan induk yang bersifat cukup (fair).

\section{Tipe Kerogen}

Analisis tipe kerogen dalam penelitian ini menggunakan diagram van Krevelen dan analisis tipe kerogen yang dapat ditentukan berdasarkan parameter nilai Indeks Hidrogen (HI) dari Peters dan Cassa (1994) [6].

Serpih Piniya pada sumur AK-2 mempunyai nilai HI berkisar $63-592 \mathrm{mgHC} / \mathrm{g}$ TOC, sumur AK-6 mempunyai nilai HI berkisar 137-174 $\mathrm{mgHC} / \mathrm{g}$ TOC, dan sumur AK-9 mempunyai nilai HI berkisar 53 $242 \mathrm{mgHC} / \mathrm{g}$ TOC. Kandungan nilai HI Serpih Piniya pada ketiga sumur (Gambar 5) mempunyai nilai berkisar 53-592 $\mathrm{mgHC} / \mathrm{g}$ TOC sehingga dapat diinterpretasikan bahwa Serpih Piniya memiliki tipe kerogen II - III (Peters dan Cassa, 1994)[6] yang dapat menghasilkan hidrokarbon berupa minyak dan gas.

\section{Kematangan Material Organik}

Kematangan batuan induk pada penelitian ini diidentifikasi berdasarkan analisis pirolisis Rock-Eval dan analisis terhadap nilai reflektansi vitrinit. Selain dapat memberikan gambaran mengenai tingkat kematangan, grafik plot nilai Tmaks dan indeks hidrogen dapat menentukan tipe kerogen serta tingkat kematangannya.

Serpih Piniya pada sumur AK-2 memiliki nilai Tmaks berkisar $413^{0}-426^{0} C$, sedangkan pada sumur AK-6 memiliki nilai Tmaks $421^{\circ} C$ dan pada sumur AK-9 Serpih Piniya memiliki nilai Tmaks berkisar $432^{0}-444^{0} C$. Grafik plot antara Tmaks dan indeks hidrogen (Gambar 6) menunjukkan bahwa Serpih Piniya pada ketiga sumur memiliki nilai Tmaks berkisar $413^{0}-444^{0} \mathrm{C}$ sehingga berada dalam tahap belum matang hingga matang dengan tipe kerogen II - III.

Analisis reflektansi vitrinit Serpih Piniya mempunyai nilai berkisar $0.29-0.6 \%$, Peters dan Cassa menyebutkan bahwa nilai reflektansi vitrinit 0.29-0.6\% termasuk ke dalam kategori belum matang hingga matang. Kematangan material organik dapat diidentifikasi pada Gambar 7, sumur AK-2 berada dalam tahap kematangan yang hampir mencapai tahap kematangan awal dibandingkan sumur AK-6 dan sumur AK-9.

\section{Penerapan Metode $\Delta \log R$}

Pembuatan log TOC dalam penelitian ini menggunakan metode $\Delta \log R$ (Passey et al., 1990)[5]. Log yang digunakan dalam perhitungan adalah $\log$ sonik dan $\log$ resistivitas. Hasil analisis geokimia berupa tipe kerogen menjadi langkah awal dalam tahapan ini. Tipe kerogen digunakan dalam penentuan Level of Maturity (LOM) dari Serpih Piniya. Penentuan Level of Maturity (LOM) merupakan salah satu parameter yang berpengaruh terhadap besar kecilnya nilai TOC Passey et al. (1990)[5].

Penelitian ini menggunakan kurva Level of Maturity dengan tipe gas prone. Grafik LOM diperoleh dari plotting nilai S2 dan nilai TOC dari sampel. Gambar 8 menunjukkan penentuan garis nilai LOM pada daerah penelitian antara LOM 9 dan LOM 10.

Tahap selanjutnya adalah menentukan $R_{\text {baseline }}$ dan $D T_{\text {baseline }}$ melakukan overlay log sonik dengan $\log$ resistivitas. Penentuan $R_{\text {baseline }}$ dan $D T_{\text {baseline }}$ ditentukan berdasarkan posisi log sonik dan log resistivitas yang berimpit.

Hasil analisis menunjukkan nilai $R_{\text {baseline }}$ pada sumur AK-6 sebesar $2 \Omega$ dan $D T_{\text {baseline }} 87.2$ usec/ft (Gambar 9 bagian a). Sedangkan, overlay dan penentuan nilai baseline pada sumur AK-9 ditunjukkan pada Gambar 9 (bagian b). Berdasarkan analisis didapatkan nilai $R_{\text {baseline }}$ pada sumur AK-9 sebesar $9.8 \Omega$ dan $D T_{\text {baseline }} 172.3 \mathrm{usec} / \mathrm{ft}$.

Perhitungan nilai TOC Passey kemudian dihitung menggunakan penentuan nilai LOM dan nilai baseline pada masing-masing sumur. Gambar 10 menunjukkan hasil perhitungan TOC Passey dalam bentuk defleksi log yang kemudian dilakukan kalibrasi dengan data TOC sampel. Tujuan dari kalibrasi ini adalah untuk melihat kesesuaian hasil perhitungan TOC Passey dengan nilai TOC sampel. Hasil kalibrasi menunjukkan keakuratan yang cukup tinggi, sehingga nilai hasil perhitungan TOC Passey dianggap baik. Log TOC ini akan diterapkan pada interval Formasi Piniya yang merupakan fokus dalam penelitian ini.

\section{Analisis Penyebaran TotalOrganicCarbon (TOC)}

Analisis crossplot dilakukan antara nilai impedansi akustik dengan nilai TOC Passey (Gambar 11), crossplot menghasilkan hubungan perbandingan terbalik. Nilai AI yang tinggi menunjukkan nilai TOC rendah. Crossplot menghasilkan persamaan untuk dilakukan konversi cube AI menjadi cube TOC dengan persamaan $T O C=0.225818 x(A I)^{\frac{1889.31442}{A I}}$.

Peta penyebaran AI dan TOC dapat dilihat pada Gambar 12. Hasil penyebaran TOC menunjukkan penyebaran TOC yang tinggi berada pada bagian 
tengah daerah penelitian. Nilai TOC meningkat seiring dengan semakin jauhnya pengendapan dari sumber batuan, hal tersebut karena karakter batuan akan semakin bersifat lempungan dan melimpahnya material organik. Area depocenter berada pada bagian tengah daerah penelitian.

\section{KESIMPULAN}

Berdasarkan penelitian yang telah dilakukan, maka didapatkan kesimpulan sebagai berikut:

Serpih Piniya disusun oleh litologi dominan serpih dengan sisipan batulanau dan batupasir. Jumlah kandungan TOC dari data sampel sebesar $0.552 w t \%$ artinya Serpih Piniya termasuk dalam kategori batuan induk yang bersifat cukup (fair) dengan tipe kerogen II - III. Litofasies serpih yang dapat menghasilkan hidrokarbon adalah organic shale. Interval organic shale pada sumur AK-6 sebanyak 46 zona dan pada sumur AK-9 sebanyak 34 zona. Perhitungan TOC Passey menghasilkan nilai TOC rata-rata sebesar $0.527 w t \%$.

Nilai TOC tinggi ditandai dengan nilai impedansi akustik yang rendah terletak pada bagian tengah daerah penelitian. Area sweet spot secara umum berada diantara sumur AK-2 dengan nilai TOC $0.552 w t \%$ serta memiliki ketebalan serpih $1200 \mathrm{~m}$. Sweet spot berada di bagian tengah daerah penelitian dengan arah baratlaut - tenggara sebagai depocenter pengendapan.

\section{PENULIS}

1 Winda Putri Anggraeni

Dari :

(1) Departemen Teknik Geologi, Fakultas Teknik, Universitas Gadjah Mada

2 Jarot Setyowiyoto

Dari :

(1) Departemen Teknik Geologi, Fakultas Teknik, Universitas Gadjah Mada

3 Ferian Anggara

Dari :

(1) Departemen Teknik Geologi, Fakultas Teknik, Universitas Gadjah Mada

Pustaka

1. Alves, F., Almeida, J.A., dan Silva, A.P. 2014.

"Simulation of Acoustic Impedance Images by Stochastic Inversion of Post-Stack Seismic Reflection Amplitudes and Well Data". Journal of

Petroleum Science and Engineering (121).
2. Atarita, T.C., Karlina, D.A., Nuratmaja, S., Puspitasari, A., dan Santosa, B.J. 2017. "Predicting Distribution of Total Organic Carbon (TOC) and S2 with $\Delta$ Log Resistivity and Acoustic Impedance Inversion on Talang Akar Formation, Cipunegara Sub Basin, West Java". Procedia Engineering (170).

3. Loseth, H., Wensaas, L., Gading, M., Duffaut, K., Springer, M. 2011. Can Hydrocarbon Source Rocks be Identified on Seismic Data?. Geological Society of America.

4. Panggabean, H. dan Hakim, A. S. 1986. Reservoir Rock Potential Of The Paleozoic-Mesozoic Sandstone Of The Southern Flank Of The Central Range, Irian Jaya. Proceedings Indonesian Petroleum Association, 15th Annual Convention. Jakarta.

5. Passey, Q.R., Creaney, S., Kulla, J.B., Moretti, F.J., dan Stroud, J.D. 1990. A Practical Model for Organic Richness from Porosity and Resistivity Logs. The American Association of Petroleum Geologist Bulletin December (74).

6. Peters, K.E., dan Cassa, M.R. 1994. Applied Source Rock Geochemistry. The Petroleum System From Source to Trap. AAPG Memoirs no. 60.

7. Sukhyar, R., dan Fakhrudin, R.. 2013. Unconventional Oil and Gas Potential in Indonesia with Special Attention to Shale Gas and Coal-bed Methane. Presentation Slide of Geological Agency of Energy and Mineral Resources. Republik Indonesia.

8. Sukmono, S. 2000. Seismik Inversi Untuk Karakteristik Reservoir. Jurusan Teknik Geofisika ITB. Bandung.

\section{DAFTAR GAMBAR}

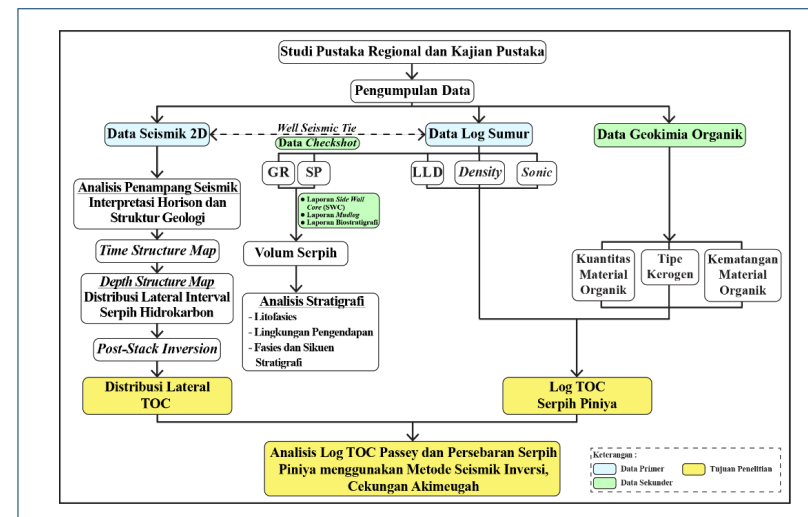

Gambar 1: Diagram alir penelitian. 


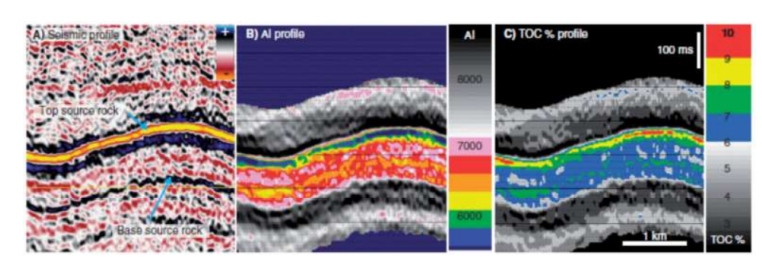

Gambar 2: A) Penampang seismik. (B) Penampang impedansi akustik yang diperoleh dari inversi data seismik. (C) Penampang TOC yang diperoleh dari konversi nilai impedansi akustik (Loseth et al., 2011)[3].

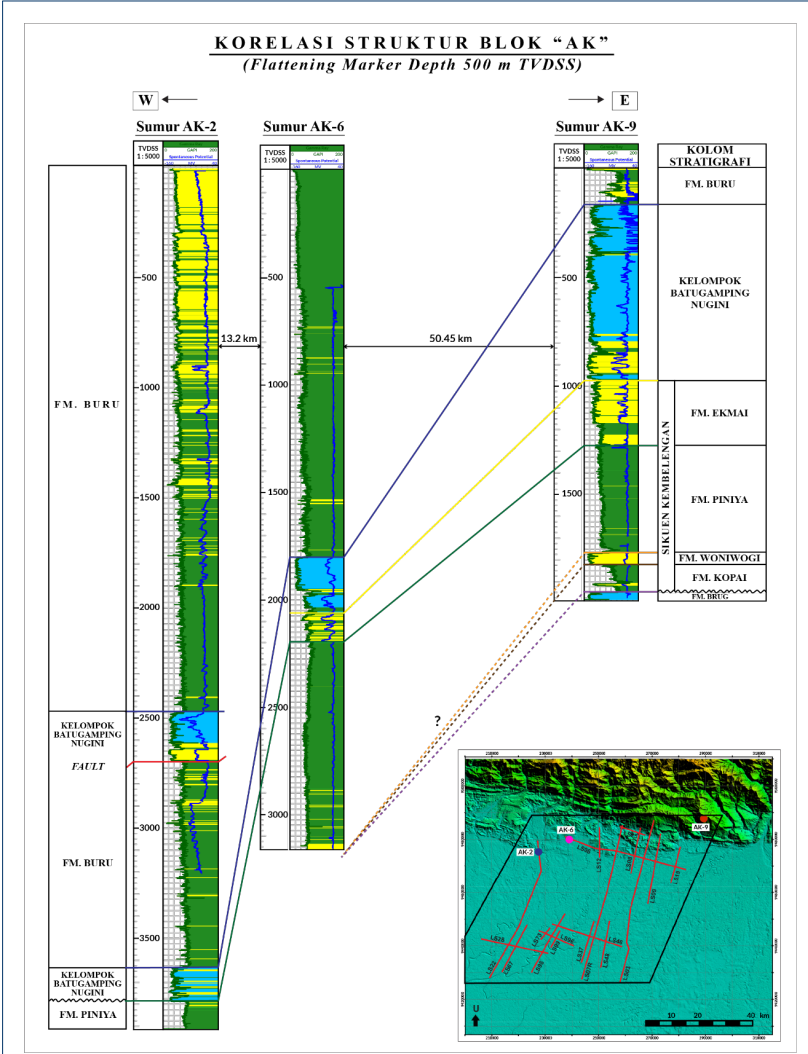

Gambar 3: Korelasi struktural dari penampang sumur dengan flattening marker kedalaman $500 \mathrm{~m}$ TVDSS menunjukkan adanya indikasi struktur geologi pada Blok "AK".
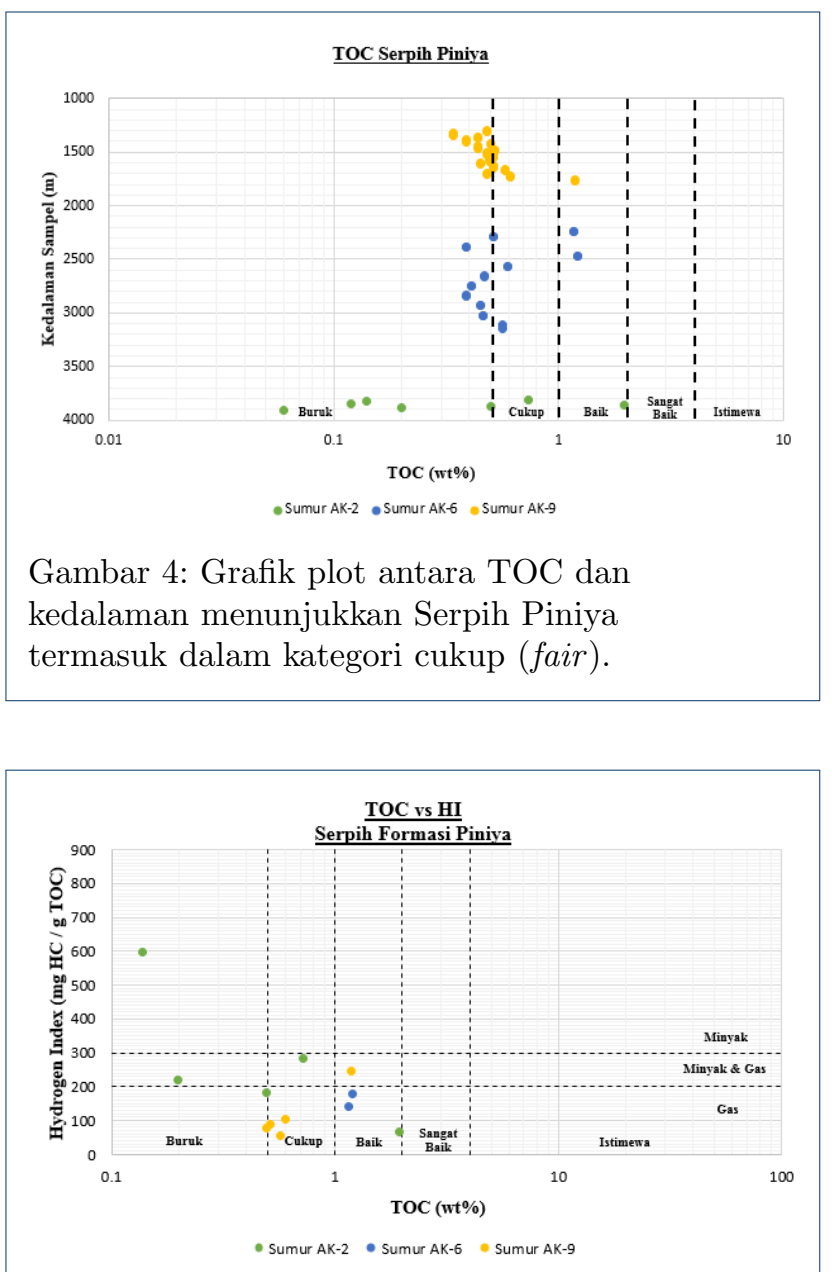

Gambar 5: Grafik plot antara TOC dan indeks hidrogen menunjukkan Serpih Piniya dapat menghasilkan hidrokarbon berupa minyak dan gas.

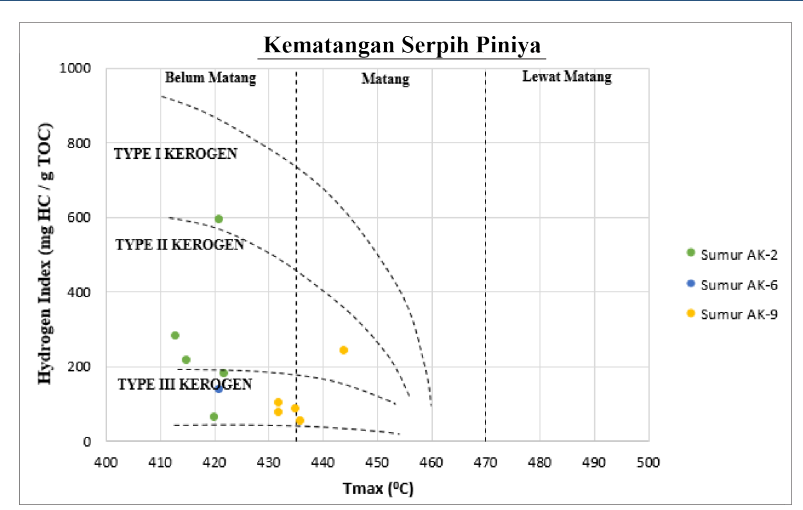

Gambar 6: Grafik plot antara Tmaks dan indeks hidrogen menunjukkan Serpih Piniya berada dalam tahap belum matang - matang dengan tipe kerogen II - III. 

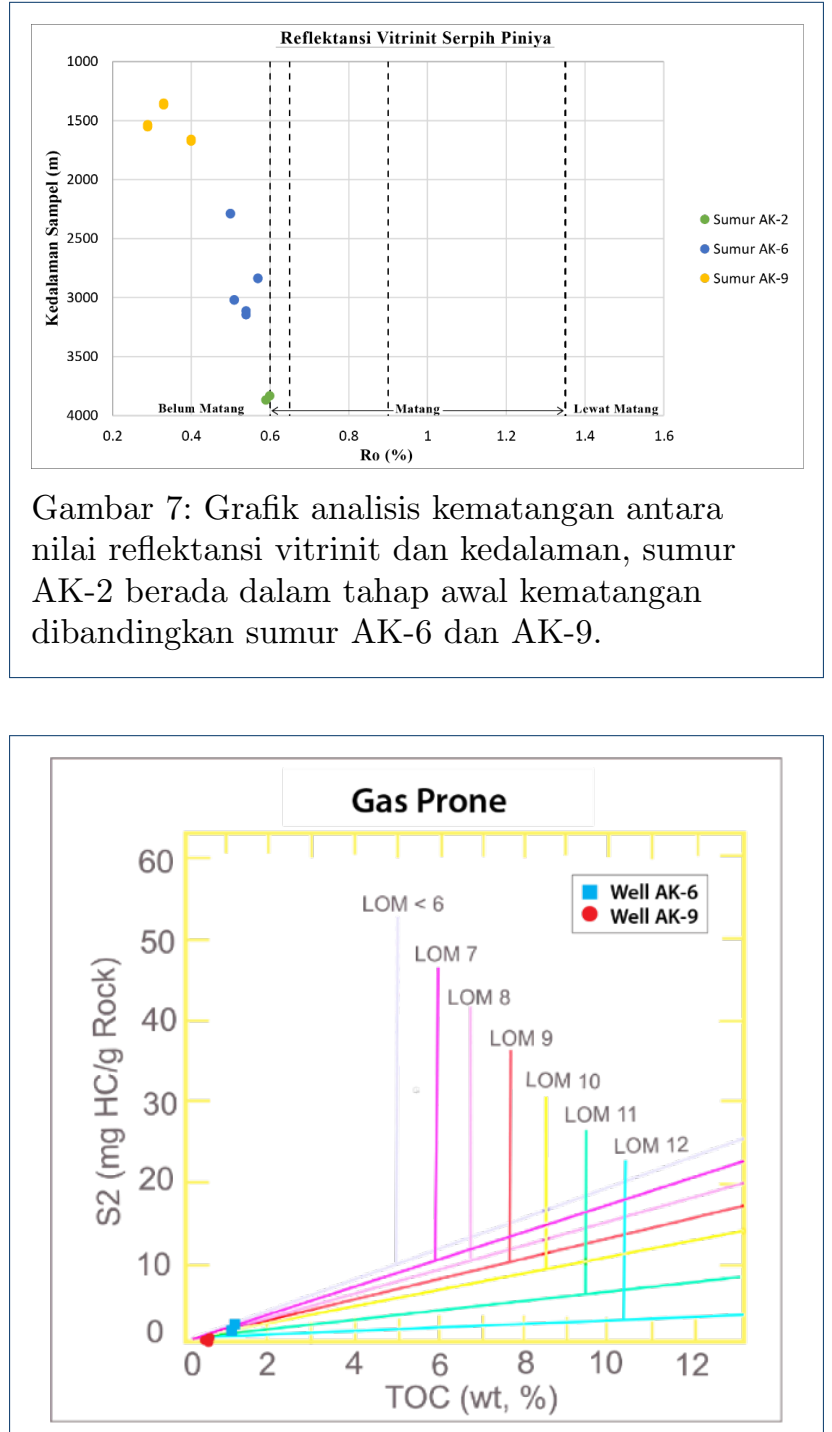

Gambar 8: Grafik level of maturity (LOM) antara nilai TOC dan S2 sampel berada pada garis LOM 9 dan LOM 10.

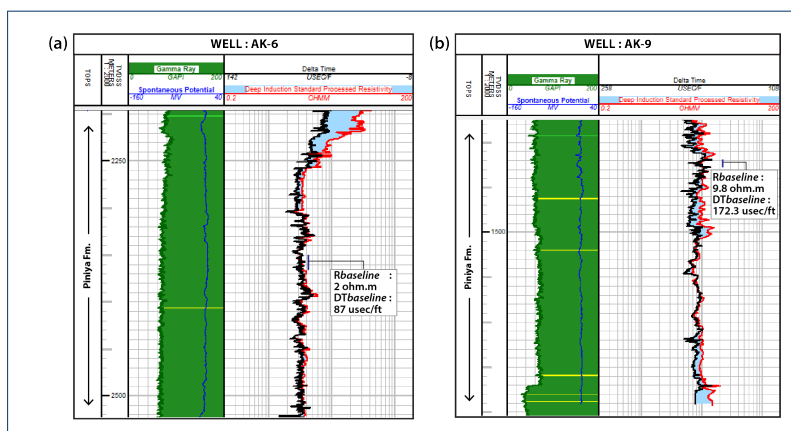

Gambar 9: Overlay log sonik dan log resistivitas yang dihasilkan pada sumur AK-6 (a) dan sumur AK-9 (b). (a)

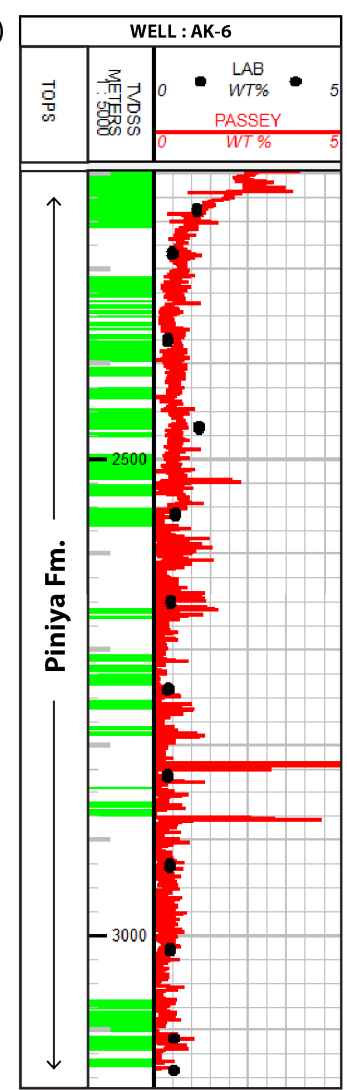

(b)

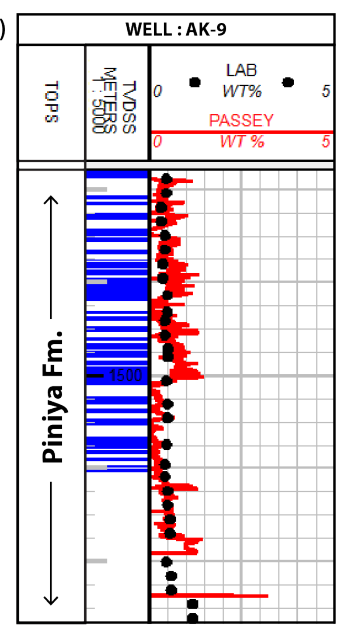

Gambar 10: Log TOC Passey pada sumur AK-6 (a) dan sumur AK-9 (b). Hasil TOC Passey diatas kemudian dikalibrasi dengan nilai TOC sampel untuk mengetahui keakuratan perhitungan tersebut.

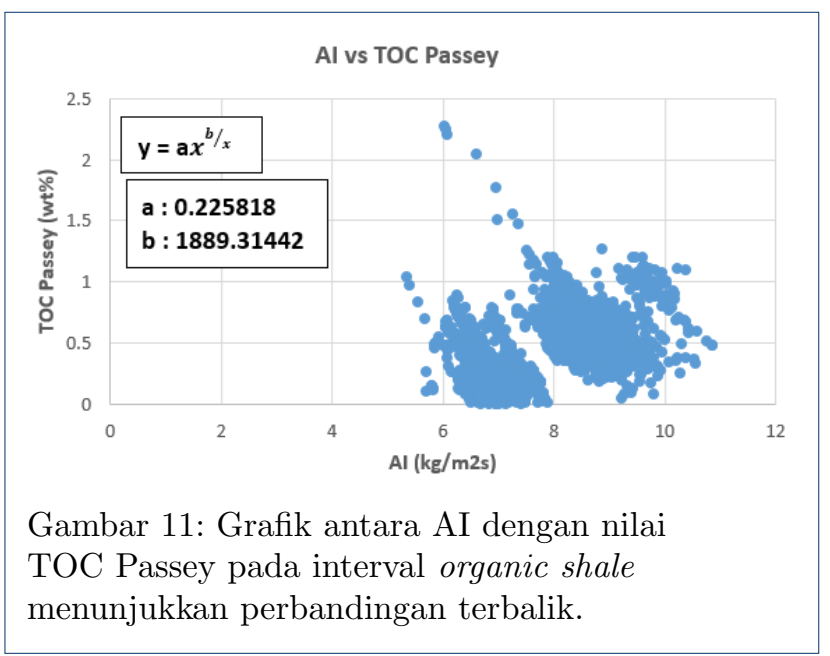




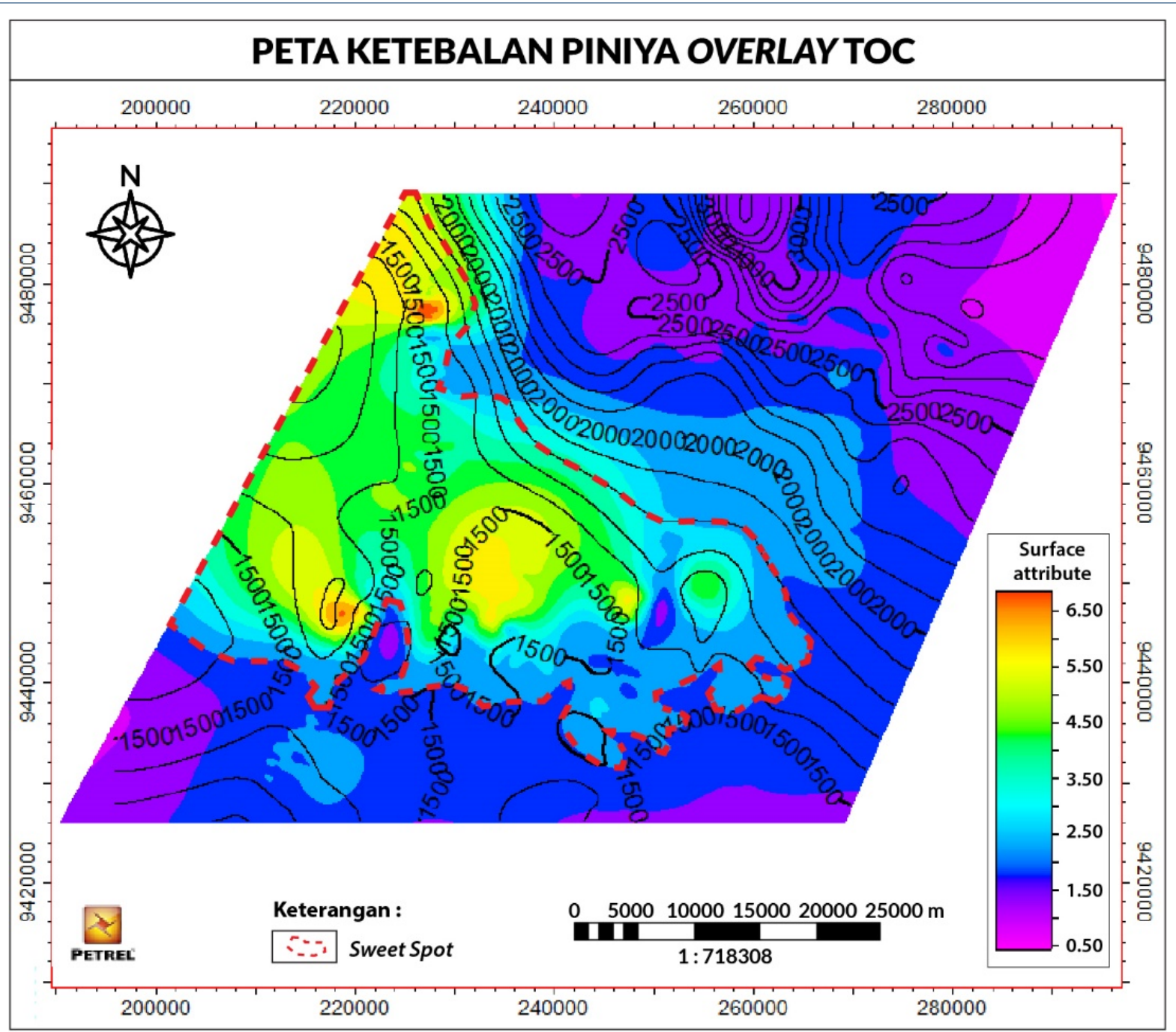

Gambar 12: Peta overlay kedalaman

Formasi Piniya dengan persebaran TOC pada

daerah penelitian. Sweetspot berada pada bagian

tengah daerah penelitian yang berarah

baratlaut - tenggara. 